\title{
Karen Routledge, Do You See Ice? Inuit and Americans at Home and Away (Chicago: University of Chicago Press, 2018). 272 pp. Hardcover \$50.00 USD.
}

What makes a place a home? This is a question that surprisingly few environmental historians have asked. And yet environment plays an enormous role in shaping understandings of the places we call home.

Karen Routledge's new study of Inuit-American relations attempts to explain how people construct ideas of home and the various ways in which the environment influences those ideas. This innovative book explores critical issues at the heart of the history of modern colonialism and situates the environment as a crucial factor in shaping cultural concepts of belonging, safety, and comfort. There is much here for scholars from a wide range of disciplines, including environmental history, cultural history, and the history of colonialism.

Across its four main chapters, Do You See Ice? is a well-structured investigation of different (and sometimes conflicting) ideas of home among American whalers and Inuit who worked together and interacted in each other's home countries in the nineteenth century. We learn about American perceptions of Arctic environments and Inuit perspectives of the temperate environments of the eastern United States. One chapter examines the views of the American whalers who hunted animals in Cumberland Sound in a country they found unfamiliar and occasionally terrifying. That country, however, was home to millennia of generations of Inuit who were neither fearful nor bewildered by the Arctic. In another chapter, we follow the remarkable lives of Hannah and Ipiirvik, an Inuit couple who left their home to live and work in the United States. They experienced challenging lives abroad in a foreign country, mixed with belittling moments on display as specimens of "authentic" Inuit for American audiences, tragedy with the loss of a child, and the establishment of enduring friendships.

Routledge also uses the case of the Lady Franklin Bay expedition to examine both Americans and Inuit in the unfamiliar landscapes of the High Arctic. More than one hundred days of darkness each year placed strains on the crew as they were stranded for three years above the Arctic circle. In the final chapter, Routledge attempts to show the reader the environments of Cumberland Sound as a home through the eyes of the Inuit families who lived there for generations. Americans failed to record much of what took place during the commercial whaling period beyond their ships and stations. Whaling and the intrusion of foreigners changed many aspects of Inuit life, but families continue to maintain connections to Cumberland Sound as home through their ongoing engagement with the land.

Do You See Ice? is a master class in empathetic scholarship. Routledge is a 
methodical historian who approaches her sources with great care and caution all in an effort to understand the subjects of her book on their own terms. Understandably, she had limited sources with which to work. This was especially true of the Inuit in this history. Still, through deliberate close reading, Routledge helps the reader see the world through the eyes of her subjects. She weighs the evidence always with a mind toward trying to understand the world in terms that would make sense to the truth of the experiences of the people who lived, worked, and played in these nineteenth-century environments. What might they have thought? How did they feel? What made them comfortable or scared? This kind of empathy in historical writing shows the strength of humanities scholarship.

Empathy is also a critical absence in Routledge's story. On many occasions, American whalers failed to see the Arctic through the eyes of those who called it home. This lack of empathy lies at the heart of the colonial history of the Arctic and beyond. We continue to live with this flawed perspective. When northern Indigenous communities suffer from contaminated water, flooding, and outbreaks of illness, southern media and politicians often blame the geography and environments of the north. Qallunaat from the south continue to struggle to understand the homes of other people.

Sean Kheraj

York University 